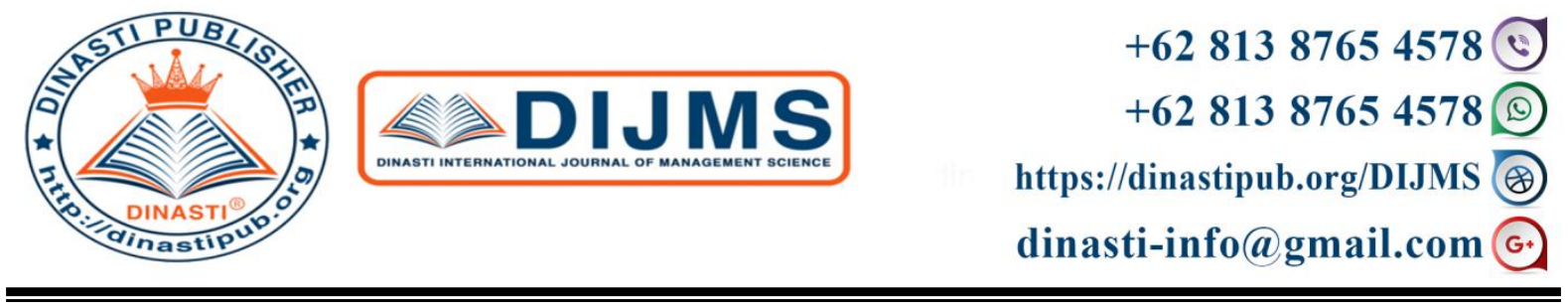

\title{
ANTECEDENTS AND CONSEQUENCES OF MEMORABLE TOURISM EXPERIENCE
}

Yadi Ernawadi ${ }^{1}$, Hariyadi Triwahyu Putra ${ }^{2}$

1) ${ }^{2)}$ University of Jenderal Achmad Yani, Cimahi, Indonesia

\begin{tabular}{|l|l|}
\hline ARTICLE INFORMATION & $\begin{array}{l}\text { Abstract: The purpose of the research is to examine the } \\
\text { Received: } 19^{\text {th }} \text { April } 2020 \\
\text { Revised: } 30^{\text {th }} \text { April } 2020 \\
\text { Issued: } 08^{\text {th }} \text { May } 2020\end{array}$ \\
$\begin{array}{l}\text { impact of destination image on tourist revisit intention. } \\
\text { Nowresponding author: } \\
\text { Yadi }\end{array}$ & $\begin{array}{l}\text { attention in marketing research area to develop its } \\
\text { operational definition related to the specific object such } \\
\text { as artificial tourism. The administered questionnaires } \\
\text { were used to collect the data from the domestic tourists } \\
\text { who were enjoying the resort. Structural equation model } \\
\text { has been used to analyze the data and examined the } \\
\text { hypotheses. The findings of the research illustrate that } \\
\text { memorable tourism experience mediates the influence of } \\
\text { destination image toward tourist revisit intention. Based } \\
\text { on the limitation of the research, the future research is } \\
\text { proposed to widen area of the research in context of } \\
\text { tourism industry besides sampling technique related to } \\
\text { generalization objective. }\end{array}$ \\
& $\begin{array}{l}\text { Keywords: Destination Image, Memorable Tourism } \\
\text { Experience, Revisit Intention }\end{array}$ \\
\hline
\end{tabular}

\section{INTRODUCTION}

One of the sector that is pledged in driving the rate of economic growth of Indonesia is tourism (Kementrian Pariwisata, 2018) that is indicated by the growth of the tourist visit around 3.26\% in 2017 and estimated rise till 295 million visits in 2019 (BPS Indonesia, 2018). By 3,46\% growth of the tourist visit, West Java is in the second position as the province which is most visited by tourist in Indonesia in 2017 (BPS Indonesia, 2018). Bandung Barat Region is the most favorite place in West Java to be visited that is illustrated by $20,33 \%$ the growth of tourist visit in 2017 and predicted rise till 3 million visits in 2018 (BPS Indonesia, 2018). Anggono (2017) expressed that the interesting point of Bandung Barat Region is mainly in its beauty of natural landscape and culture. Beside those of the reasons, more and more artificial tourism destinations stimulate he tourists to visit the region (Anggono, 2017). Most of favorite tourism destination in the region is artificial tourism that consists of The Lodge Maribaya, Floating Market Lembang, Dago Dream Park, De'Ranch, 
Farm House Susu Lembang, Dusun Bambu, dan Orchid Forest Cikole (Sodikin, 2017; Wisata Bandung, 2018; Trishandiani, 2018). One among the destinations that combine the concepts of education-tourism, ecotourism, sport-tourism and the beauty of pine forest with the variation of orchid types is Orchid Forest Cikole Lembang (Sakti, 2018). The Ministry of Tourism of Indonesia authenticated the tourism destination as the digital destination pilot project that carried on nomadic tourism and ecotourism in $24^{\text {th }}$ of August 2018 as one of the strategy to reach 295 million tourist visits in Indonesia (Sakti, 2018).

Indonesian Government through the related ministry has tied some co-operations with the tourism actors in increasing promotion, attraction quality, amenities, and accommodation to push the visit intention of the potential tourists in 2018 (Anggono, 2017). Intention to visit is an important element of the loyalty concept. Whilst, the revisit of tourists to a particular tourism destination is influenced by their satisfaction based on the experiences (Guntoro, 2013). According to Som et al (2012) the intention to visit is emerged by the perception and feeling of the tourists about the tourism destination. Chiu et al (2016) convey that to maintain the tourists in order to be willing to visit the tourism destination is more efficient than attract the new ones. Meanwhile, Kim (2014) illustrate that the tourists want to obtain memorable tourism experience (MTE), the interaction opportunity with another tourist, the interaction opportunity with local residents at the time they visit the destination. Therefore, MTE is a crucial matter that should be created by the tourism business actors to increase the competitiveness advantages (Zhang et al, 2018). MTE can be created through the unique experience that is given by the providers in order to have a willingness to revisit the tourism destination (Mahdzar et al, 2015). MTE is the most factor that influence in determining the behavioral intention (Kim, 2014). Whilst Zhang et al (2018) clarify that MTE mediates the impact of destination image on visit intention of the tourist.

\section{LITERATURE REVIEW}

Destination image is the set of believes, ideas, and impressions of individual about a particular object, place, or destination. (Zhang et al, 2018). Image is used in context assessing a product, brand, and organization related to purchase decision (Hallmann et al, 2015). Destination image is defined as the perception of a tourist and a tourism provider about all of destination attributes that has an important role in delivering the destination value (Hallmann et al, 2013). Whilst Stylos et al (2017) explain that the destination image as a reflection of the perception of the visitors about the destination which is saved in their memory. Thus Assaker (2014) assert that the destination image is the set of impressions, ideas, expectation, thoughts, and emotions that is remembered by the visitors about the destination. In the other hand, consumer consumption experience can be integrated in a situation through experience exhibition with the result able to create unforgettable experience (Damodaran, 2014). Meanwhile, the memory that has destination orientation dominate the reason of the youth tourists in considering a certain destination as something memorable followed by social orientation and personal orientation (Loncaric et al, 2019). The memory based on destination oriented consists of physical attributes and destination image. According to Lu et al (2015) there is relationship between destination image and tourist experience.

Kim explores the destination attributes that are associated with MTE and found that the attributes are included as destination image about local culture, activity variation, hotel management, infrastructure, environmental management, easy to access, service quality, place attachment, and superstructure. In accordance with Selaras Zhang et al (2018) that state destination image has a direct impact on MTE. According to Pratmaningsih et al (2014) destination image also influence the tourist intention to revisit the destination. In accordance 
with the similar research, Hallmann et al (2015) find that the destination image has a positive impact on the tourist intention to revisit the destination. Whilst, Tan \& Wu (2016) have found that the cognitive and affective of destination image are the main factors influence the intention of tourist to revisit the tourism object in Hongkong. Stylos at al (2017) add that the conative of destination image has a positive and direct impact on revisit intention of the tourists. Thus the first and second hypothesis is stated as follows:

$\mathrm{H}_{1}$ : Destination image has a positive impact on MTE.

$\mathrm{H} 2$ : Destination image has a positive impact on revisit intention.

According to Adhikara \& Bhattacharta (2014) a tourist is willing to spend amount of cost to do some tourism activities in obtaining an experience. Delivering an experience is more important than the tourism product itself (Mei, 2014). A destination that gives a memorable unique experience will more sustainable in a competition (Chandralal \& Valenzuela, 2013; Mazurek, 2014; Zolvani et al, 2015). Kim (2014) explains that the tourism experience uniqueness is called as memorable tourism experience (MTE). Thus, Sotiriadis (2017) describes that entertainment, knowledge, beauty, and differentiation that are experienced by the tourist is called as memorable experience. However, memorable experience will lead the tourists to make a decision related to their plan of traveling to revisit the same object in the future (Zhang et al, 2018). An intention to revisit a particular destination is a post purchase behavior in decision making of consumer (Kotler \& Keller, 2016). A satisfied consumer tends to repurchase and delivers a positive word of mouth (Kotler \& Keller, 2016). Revisit intention is the willingness of a tourist revisit the same destination related to his or her satisfied experience (Chien, 2016). There are some indicators to be used in measuring revisit intention consist of the tourist tendency to revisit, willingness to revisit, and the possibility to revisit the destination in the future (Zhang, 2017).

Based on the research that has conducted by Samdin et al (2013) is known that the happiness experience is not only describes the perception of the tourist but is also be able to predict thee intention to revisit effectively (Kim, 2014). Furthermore, Kim (2014) explain that revisit intention, retaking the same tourism program, and to promote the destination through word of mouth are influenced by MTE. Meanwhile, Tsai (2016) discovers the same finding with the previous research. In accordance with the previous research, Zhang et al (2018) assure that MTE mediates the influence of destination image toward the tourist revisit intention. The relationship among the concepts discussed above is illustrated in picture 1 . Thus, the third hypothesis is developed as follows:

$\mathrm{H}_{3}$ : MTE has a positive impact on revisit intention

$\mathrm{H}_{4}$ : MTE mediates the influence of destination image on revisit intention.

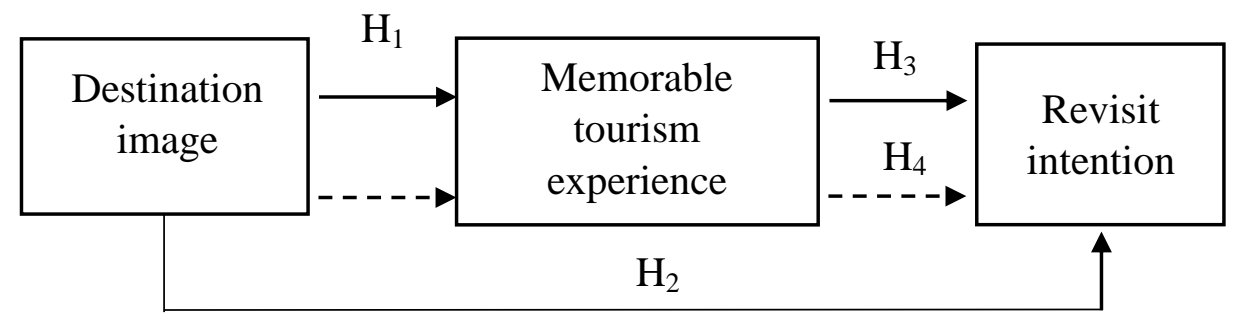

Picture 1. Conceptual Model 


\section{RESEARCH METHODS}

Such as the aim of this research is to examine the hypothesis based on quantitative research approach, then causal method has taken to explain the relationship among the variables. The population characteristic must be a tourist who has enjoyed Orchid Forest Cikole Lembang Bandung Region. The tourism destination of the research was taken by considering some reasons related to its specific characteristic as artificial nature tourism that combines education, ecotourism, and nomadic tourism. Whilst, from 180 data that was collected, there are 152 appropriate with the criteria to classify as sample members. Convenience sampling is used in process of collecting data due to demographic, geographic, and behavioral characteristics of the tourists as the sample of the research.

The administered questionnaires are suitable to be used as the instrument of the research. The instrument contains of 28 validated and reliable items that is shown on table 1 . Confirmatory factor analysis (CFA) is used to measure construct validity and reliability. The construct is categorized as the valid one if the loading factor value $(\lambda)$ more than 0.5 , meanwhile it is classified as the reliable construct if the composite reliability $(\mathrm{CR}) \geq 0.7$. It is necessary to inform that the distribution of the data indicates is not normal. Thus, to estimate the model is explained by using maximum likelihood (ML) method and correcting some general methods by using asymptotic covariance matrix. Furthermore, structural equation model with LISREL has been used in analyzing the data research.

\section{Table 1.}

The Instrument Validity and Reliability

\begin{tabular}{|c|c|c|c|c|c|}
\hline Construct & Indicators & $\lambda$ & $\lambda^{2}$ & e & $\mathbf{C R}$ \\
\hline Destination & The nature of environment & 0,62 & 0,384 & 0,616 & 0.815 \\
\hline \multirow[t]{5}{*}{ image } & The cleanliness of the destination & 0,70 & 0,490 & 0,510 & \\
\hline & The free of pollution & 0,64 & 0,410 & 0,590 & \\
\hline & The convenience in activities & 0,57 & 0,325 & 0,675 & \\
\hline & $\begin{array}{l}\text { The easiness to access by public } \\
\text { transportation }\end{array}$ & 0,67 & 0,449 & 0,551 & \\
\hline & The easiness to shop at the venue & 0,60 & 0,360 & 0,640 & \\
\hline \multirow{16}{*}{$\begin{array}{l}\text { Memorable } \\
\text { tourism } \\
\text { experience }\end{array}$} & The happiness feeling after the visit & 0,51 & 0,260 & 0,740 & 0.925 \\
\hline & The enjoyment of the atmosphere & 0,51 & 0,260 & 0,740 & \\
\hline & The involvement with the atmosphere & 0,57 & 0,325 & 0,675 & \\
\hline & The astonishment to the atmosphere & 0,53 & 0,281 & 0,719 & \\
\hline & The feeling of most lovely impression & 0,64 & 0,410 & 0,590 & \\
\hline & The feeling of uniqueness experience & 0,67 & 0,449 & 0,551 & \\
\hline & The feeling of difference experience & 0,71 & 0,504 & 0,496 & \\
\hline & The feeling of quite & 0,70 & 0,490 & 0,510 & \\
\hline & The feeling to be free & 0,55 & 0,303 & 0,698 & \\
\hline & The feeling of freshness & 0,70 & 0,490 & 0,510 & \\
\hline & The feeling of relax & 0,40 & 0,160 & 0,840 & \\
\hline & The meaningful of the visit & 0,61 & 0,372 & 0,628 & \\
\hline & The importance of the visit & 0,68 & 0,462 & 0,538 & \\
\hline & The opportunity to learn something & 0,71 & 0,504 & 0,496 & \\
\hline & The expected destination & 0,67 & 0,449 & 0,551 & \\
\hline & The activity enjoyment during the visit & 0,64 & 0,410 & 0,590 & \\
\hline
\end{tabular}


The attractiveness of destination

$0,64 \quad 0,410 \quad 0,590$

The exploration during the visit

$0,71 \quad 0,504 \quad 0,496$

The obtained knowledge during the visit

$0,51 \quad 0,260 \quad 0,740$

Revisit

Possibility to revisit

$\begin{array}{lll}0,83 & 0,689 & 0,311\end{array}$

0.844

intention

Willingness to revisit
Future plan to revisit

$0,80 \quad 0,640 \quad 0,360$

$0,91 \quad 0,828 \quad 0,172$

\section{FINDINGS AND DISCUSSION}

P-value of skewness and kurtosis of one indicator of brand image $<0.05$ based on the test of univariate normality for continuous variables. It means that the indicator is not used in the next step of analysis. Whilst p-value of skewness and kurtosis of and test of multivariate normality for continuous variables indicates that the data has not categorized as the normal data. Thus, maximum likelihood (ML) method is used to estimate the model and asymptotic covariance matrix to correct several customs where the path diagram of standardize solution is shown on picture 2 .

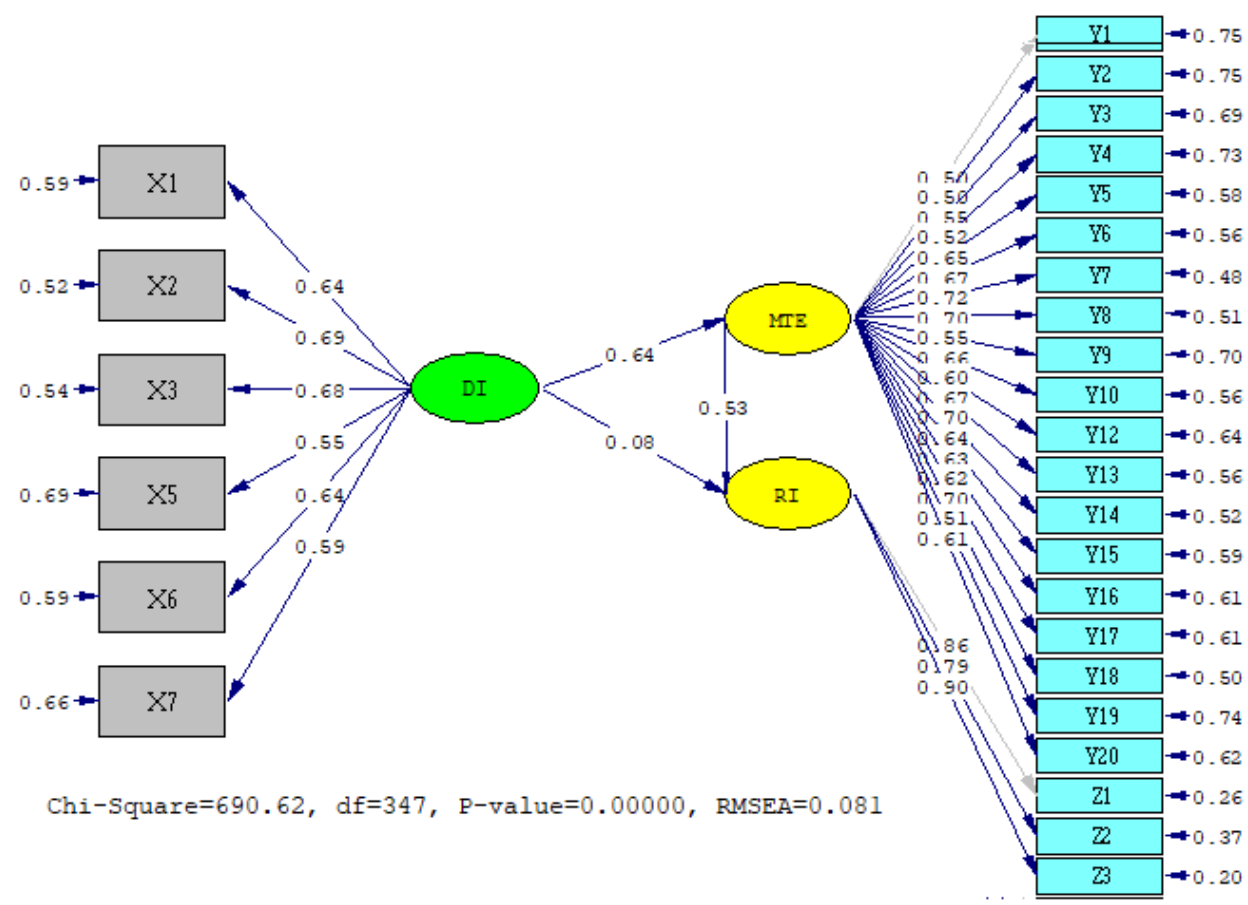

Picture 2. Research Model

Based on asymptotic covariance matrix method is known that the six criteria included good fit as it is shown on table 2 .

Table 2.

Interpretation of Fit Model

\begin{tabular}{cccc}
\hline \multirow{2}{*}{ Goodness of Fit Index } & Cut-off Value & \multicolumn{2}{c}{$\begin{array}{c}\text { Asymptotic } \\
\text { Covariance Matrix }\end{array}$} \\
\cline { 3 - 4 } & & 840,72 & \\
\hline Chi square & & 2,42 & Good Fit \\
$\mathrm{X}^{2} / \mathrm{df}$ & $\geq 0,05$ & 0,00 & Bad Fit
\end{tabular}




\begin{tabular}{cccc} 
NFI & $\geq 0,9$ & 0,90 & Good Fit \\
PNFI & $\geq 0,9$ & 0,83 & Marginal Fit \\
CFI & $\geq 0,9$ & 0,95 & Good Fit \\
IFI & $\geq 0,9$ & 0,95 & Good Fit \\
RFI & $\geq 0,9$ & 0,89 & Marginal Fit \\
RMR & $<0,1$ & 0,04 & Good Fit \\
RMSEA & $<0,08$ & 0,09 & Good Fit \\
\hline
\end{tabular}

Structural model that is used indicates the relationship among latent variables. Refers to the output of LISREL, the test of hypothesis is summarized on table 3 . The path coefficient shows the positive directions on all of hypothesis that it means the increase in variable independent will give an impact on the increase of dependent variable. Meanwhile, F-value is $38.379>$ F-table (3.057) has a meaning that destination image (DI) and memorable tourism experience (MTE) simultaneously give a significant impact on revisit intention (RI).

Table 3.

Hypothesis Testing.

\begin{tabular}{ccccc}
\hline Hypothesis & Relationship & $\begin{array}{c}\text { Path } \\
\text { Coefficient }\end{array}$ & t -value & Meaning \\
\hline H1 & DI -> MTE & 0,64 & 3,86 & Supported \\
H2 & DI -> RI & 0,08 & 0,62 & Not supported \\
H3 & MTE -> RI & 0,53 & 3,86 & Supported \\
\hline
\end{tabular}

Furthermore, the result of Sobel test shows the role of MTE in mediating the impact of DI on RI. Based on the mediation test of Sobel is known that t-value 3.204 more than $t$ table 1.96 as is shown on table 4 . Thus, hypothesis 4 is supported.

Table 4.

Hypothesis.

\begin{tabular}{ccccccccc}
\hline \multirow{2}{*}{ Relationship } & \multicolumn{2}{c}{ Path } & Indirect & \multicolumn{2}{c}{ Standard of Error } & & \\
\cline { 5 - 7 } & Coefficient & Impact & & \multicolumn{2}{c}{ Direct } & Indirect & t-value & t-table \\
& $\mathbf{a}$ & $\mathbf{b}$ & $\mathbf{a b}$ & $\mathbf{S a}$ & $\mathbf{S b}$ & $\mathbf{S a b}$ & & \\
\hline DI-MTE & 0,640 & & 0,339 & 0,120 & & 0,106 & 3,204 & 1,960 \\
MTE-RI & & 0,530 & & & 0,130 & & & \\
\hline
\end{tabular}

The result of this research shows that DI has a positive and significant impact on MTE. It means that the higher of DI the higher of MTE the tourists of Orchid Forest Cikole Lembang Kabupaten Bandung Barat. The seven scales that are used to measure the construct of DI reflects the set of believe, idea, and impression that the tourists have about a tourism destination refers to Zhang (2018). Thus, the finding of this research in accordance with the statement that is expressed by Damodaran (2014) that consumption experience has an opportunity to be integrated in a situation through experience exhibition so it can create memorable experience. Besides that, the finding of this research support Loncaric et al (2019) that explain that the destination oriented memory dominates the reasons of youth tourist to consider a particular destination as memories followed by social and personal oriented memories. Whilst, destination oriented memory in this research come from physical and nonphysical attributes of destination tourism. The result of this research also strengthen the finding of Lu et al (2015) that explain that there is relation between DI and tourist experience 
that also support the finding of the research by Zhang (2018). Nevertheless, this research does not explain all of the attributes related to the tourism destination refers to the idea of Kim (2014) that explores its association with memorable tourism experience consist of local culture, variation of activities, hotel, infrastructure, environmental management, accessibility, service quality, physiography, place attachment, and superstructure. Thus the further research can involve wider destination attributes to identify its influence toward MTE till gives a bigger contribution scientifically and managerially.

According to Kim (2018), the uniqueness that is felt by the tourist form unforgettable experience which is called as MTE. Meanwhile, Samdin at al. (2013) express that a happiness experience is not only the manifestation of perception of the tourists but also can be used to predict their revisit intention. This research also explain that MTE has a significant impact on revisit intention of the tourist of Orchid Forest Cikole Lembang Kabupaten Bandung Barat. In accordance with Zhang et al (2018) that deliver that there is positive MTE on revisit intention. Besides that, this research supports the explanation that is delivered by Kim (2018) MTE has appositive impact on behavioral intention to visit the same tourism destination, taking the same tourism program, and promoting it into positive word of mouth. Nevertheless, revisit intention in this research is constructed by three indicators as can be seen on table1. Therefore, there is an opportunity for the further researchers to develop the construct by adding some another indicator. Although there no significant impact of DI on RI but MTE has a significant role in mediating the relationship between both of variables. Thus, this research shows the support to explanation by Tsai (2016) that discover that revisit intention is impacted by MTE. As an additional, Zhang et al (2018) state that MTE mediates the relationship between DI and RO.

\section{CONCLUSION AND SUGESTION}

The result of this research is accordance with the aim of this research that discover that MTE has a significant role in mediating the impact of DI on RI. The finding of this research strengthen the previous propositions to develop the hypothesis. In another hand, this research still has some limitations. The further research can broader the population characteristics to another types of tourism. It is suggested in order to have opportunities to generalize the result of the research better. Besides that, the sample size is also the constraint of this research related to the sampling method that is used. Purposive sampling is suggested to be used for the future research with the bigger sample size in order to get better in generalization.

\section{REFERENCE}

Adhikari, A., \& Bhattacharta, S. (2014). Appraisal of literature on customer experience in tourism sector: review and framework. Journal Current Issue in Tourism, 19(4) 1-26. https://doi.org/10.1080/13683500.2015.1082538

Anggiono, R. (2017). "Banyak Potensi Wisata Tapi Pendapatan Minim", http://jabarekspres.com/ 2017/banyak-potensi-wisata-tapi - pendapatan-minim/amp/ retrieved September 26th, 2018.

Assaker, G. (2014). Examining a hierarchical model of Australia's destination image. Journal $\begin{array}{llll}\text { of Vacation } & \text { Marketing, } & 20 & \text { (3), }\end{array}$ https://doi.org/10.1177\%2F1356766714527104

Badan Pusat Statistik Indonesia. (2018). "Statistik Indonesia 2018”. https;//www.bps.go.id/ publibation/2018/07/03/5a963c1ea9b0fed6497d0845/ statistic - indonesia - 2018.html. retrieved September $26^{\text {th }}, 2018$. 
Chandralal, L., \& Valenzuela, F. (2013). Exploring memorable tourism experiences: Antecendents and behavioural outcomes. Journal of Economics, Business and Management, 1(2), 177-181

Chien, M. C. (2017). An empirical study on the effect of attractiveness of ecotourism destination on experiential value and revisit intention. Applied Ecology and Environmental Research, 15(2), 43-53. https://doi.org/10.15666/aeer/1502_043053

Chiu, W., Zeng, S., \& Cheng, P. S. T. (2016). The influence of destination image and tourist satisfaction on tourist loyalty: a case study of Chinese tourists in Korea. International Journal of Culture, Tourism, and Hospitality Research, 10(2), 223-234. https://doi.org/10.1108/IJCTHR-07-2015-0080

Damodaran, K. (2014). Willingness to pay for common property resources: a study in Cuddalore District, Tamil Nadu. International Journal of Interdisciplinary Research, 1 (7), 1-6.

Guntoro, B., \& Hui, T.-K. (2013). Travel satisfaction and revisit intention of chinese visitors: The case of singapore. Advance in Hospitality and Leisure, 9, 29-47

Hallmann, K., Zehrer, A., \& Müller, S. (2015). Perceived destination image: an image model for a winter sports destination and its effect on intention to revisit. Journal of Travel Research, 54(1), 94-106. https://doi.org/10.1177/0047287513513161

Kementerian Pariwisata. (2018). "Kemenpar Siap Rebut Pasar Wisatawan Millenials", https://www.google.com/amp/s/ www. idntimes. com/ news/ indonesia/amp/kementerian-pariwisata/wisatawan-millenial - jadi - pasar -kemenpar csc?espv=1, retrieved September $20^{\text {th }}, 2018$

Kim, J. H. (2014). The antecedents of memorable tourism experiences: the development of a scale to measure the destination attributes associated with memorable experiences. Tourism Management, 44, 34-45. https://doi.org/10.1016/j.tourman.2014.02.007

Kim, J. H. (2018). The impact of memorable tourism experiences on loyalty behaviors: the mediating effects of destination image and satisfaction. Journal of Travel Research, 57(7), 856-870. https://doi.org/10.1177/0047287517721369

Kotler, P., \& Keller, K. L. (2016). Marketing management $\left(15^{\text {th }}\right.$ ed.). London: Pearson Education

Lončarić, D., Perišić Prodan, M., \& Dlačić, J. (2019). The role of market mavens in cocreating tourist experiences and increasing loyalty to service providers. Economic Research-Ekonomska Istraživanja, 32(1), 2252-2268. https://doi.org/10.1080/1331677x.2019. 1645713

Lu, L., Chi, C. G., \& Liu, Y. (2015). Authenticity, involvement, and image: evaluating tourist experiences at historic districts. Tourism Management, 50, 85-96. https://doi.org/10.1016/j.tourman.2015.01.026

Mahdzar, M., Shuib, A., Ramachandran, S., Herman, S., \& Afandi, M. (2015). The role of destination attributes and memorable tourism experience in understanding tourist revisit intentions. \& Environ. Sci.Tourism \& Environment, Social and Management Sciences, 15, 32-39. https://doi.org/10.5829/idosi.aejaes.2015.15.s.205

Mazurek, M. (2014). Competitiveness in tourism - models of tourism competitiveness and their applicability: Case study Austria and Switzerland. European Journal of Tourism, Hospitality and Recreation Special Issue, 73-94

Pratminingsih, A. S., Rudatin, L. C. \& Rimenta, T. (2014). Roles of motivation and destination 1mage in predicting tourist revisit intention: a case of bandung-indonesia. International Journal of Innovation, Management and Technology, 5(1), 19-24.

Samdin, Z., Abdul Aziz, Y., Radam, A., \& Yacob, M. R. (2010). Factors influencing the 
willingness to pay for entrance permit: the evidence from taman Negara National Park. Journal of Sustainable Development, 3(3). https://doi.org/10.5539/jsd.v3n3p212

Sakti, G. (2018). "Siaran Pers: Orchid Forest Cikole: Paket Lengkap Nomadic Tourism, Ecotourism, Destinasi Digital Jadi Satu," http://www.kemenpar.go.id/asp/detil. asp?c $=16 \&$ id $=4494$, retrieved November $10^{\text {th }}, 2018$

Sodikin, A. (2017). "Inilah 5 Destinasi Wisata Keluarga di Sekitar Lembang Bandung Barat", https://travel.kompas.com/read/2017/10/15/120924927/-inilah - 5 - destinasi - wisata keluarga - di - sekitar - lembang - bandung-barat, retrieved October $7^{\text {th }}, 2018$.

Som, A. P. M., Marzuki, A., Yousefi, M., \& Khalifeh, A. N. (2012). Factors influencing visitors' revisit behavioral intentions: A case study of Sabah, Malaysia. International Journal of Marketing Studies, 4 (4), 39

Sotiriadis, M. (2017). Experiential dimensions and their influence on behavioral intentions within the context of nature-based tourism. Tourism and Hospitality Management, 23(1), 35-50

Stylos, N., Bellou, V., Andronikidis, A., \& Vassiliadis, C. A. (2017). Linking the dots among destination images, place attachment, and revisit intentions: A study among British and Russian tourists. Tourism Management, 60, 15-29. https://doi.org/10.1016/j.tourman.2016.11.006

Tan, W. K., \& Wu, C. E. (2016). An investigation of the relationships among destination familiarity, destination image and future visit intention. Journal of Destination Marketing and Management, 5(3), 214-226. https://doi.org/10.1016/j.jdmm.2015.12.008

Trishandiani, H. (2018). "Orchid Forest Cikole, Destinasi Favorit Wisatawan Milenial', https:// news. okezone. com/ amp/ 2018/ 08/ 25/ 1/ 1941346/ orchid - forest - cikole destinasi - favorit - wisatawan - milenial, retrieved November $10^{\text {th }}, 2018$

Tsai. (2016). Management of archaeological and heritage attractions: a case study of. tourism, 505(January), 487-505. https://doi.org/10.1002/jtr

Wisata Bandung. (2018). "Orchid Forest Cikole, Destinasi Wisata Favorit Kekinian di Bandung”, https://www.wisatabdg.com/2018/08/orchid-forest-cikole-destinasi-wisata. html? $\mathrm{m}=1$, retrieved November $10^{\text {th }}, 2018$

Zhang, H., Wu, Y., \& Buhalis, D. (2018). A model of perceived image, memorable tourism experiences and revisit intention. Journal of Destination Marketing and Management, 8(June), 326-336. https://doi.org/10.1016/j.jdmm.2017.06.004

Zolfani, S. H., Sedaghat, M., Maknoon, R., \& Zavadskas, E. K. (2015). Sustainable tourism: a comprehensive literature review on frameworks and applications. Economic ResearchEkonomska Istrazivanja, 28(1), 1-30 